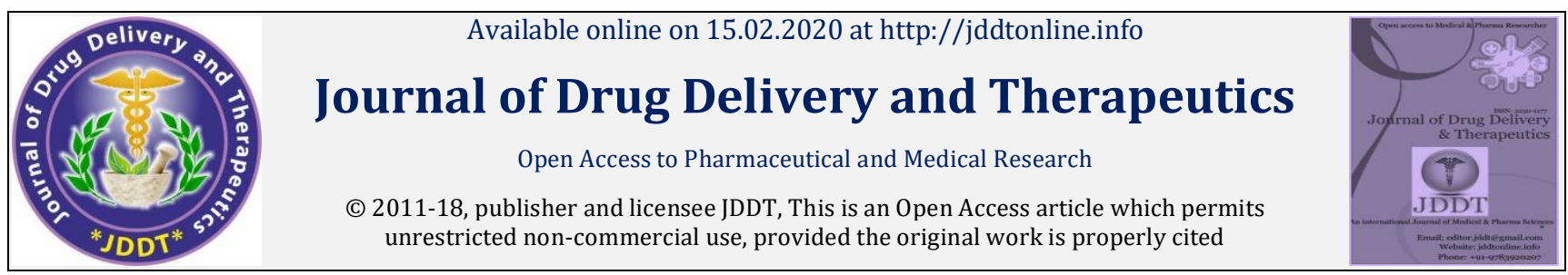

Open $\odot$ Access

Review Article

\title{
Physiological Perspectives of Ashti Dhatu and Role of Basti Chikitsa towards the Health Restoration of Ashti Dhatu
}

\author{
Rahul Sukhdev Bankar \\ Associate Professor, Department of Kriya Sharir, Shree Ram Ayurvedic Medical College and Hospital, Meerut, Uttar Pradesh, India
}

\begin{abstract}
Asthi is one of the important Dhatu amongst the many other Dhatus of body which mainly involve in Sharira dharana function, it provide shape and physical built up of body and protect internal organs from external shock. The equilibrium of Asthi dhatus helps to restore normal health status while disturbed functioning of Asthi dhatus leads pathological states. The disturbance in Asthi dhatus may be Vriddhi or Kshaya that further leads many other bone disorders. The ayurveda described various approaches to restore physiological health of Asthi dhatus and Basti chikitsa is one of them. Considering thus present article summarizes physiological aspects of Asthi dhatus and role of Basti chikitsa towards the management of pathological disturbances related to the Asthi dhatus.
\end{abstract}

Keywords: Ayurveda, Asthi dhatus, Basti chikitsa, Physiology

Article Info: Received 21 Nov 2019; Review Completed 26 Jan 2020; Accepted 30 Jan 2020; Available online 15 Feb 2020

Cite this article as:

Bankar RS, Physiological Perspectives of Ashti Dhatu and Role of Basti Chikitsa towards the Health Restoration of Ashti Dhatu, Journal of Drug Delivery and Therapeutics. 2020; 10(1-s):218-220 http://dx.doi.org/10.22270/jddt.v10i1-s.3898

*Address for Correspondence:

Dr Rahul Sukhdev Bankar, Associate Professor, Department of Kriya Sharir, Shree Ram Ayurvedic Medical College and Hospital, Meerut, Uttar Pradesh, India

\section{Introduction}

Ayurveda is considered as one of the primary health science of ancient India. The major approaches of ayurveda help to establish health and longevity. The balancing state of Doshas, Dhatu \& Agni provides normal health status and keep person away from diseases. The normal functioning of Dhatus constitutes biological units of body and maintains physiological regulations of vital organs ${ }^{1-4}$. Ayurveda described seven Dhatus and Asthi dhatu is one of them. Ayurveda mentioned that the general structure of Asthi dhatu remains unchanged during life span since it is predominate with Prithvi Mahabhoot which imparts stability. Asthi is considered as place of air; Vata dosha. When Vata increase there may be decrease in quality of Asthi. Therefore maintaining Vata dosha is considered as prime approach for the management of irregularities related to Asthi dhatu. Further, Bastichikitsa is best when management of Vata dosha is intended 2-5.

\section{Physiological role of Asthi dhatu}

* Dharana is the main function of Asthi dhatu that gives shape to the body and maintain structural framework.

* Asthi dhatu protects organs of body from external shock.
* Avalamban (maintain erect posture of body).

* Nibandhan (provide strength and stability to Mamsa and Sira).

* Asthi dhatu support Majja Dhatu.

* Mala poshana is another function of Asthi dhatu.

* Physical strength and compactness of body supported by Asthi dhatu

* Asthi dhatu connects tissues and establishes coordination for various physiological activities including movement.

\section{Abnormalities related to Asthi dhatu}

Asthi Daurbalya, Asthi Saushirya, Pratatm Vata Roga, Asthi Nistoda and Timir Darshnam, etc. are some major abnormalities related to Asthi dhatu.

\section{$>\quad$ Asthi vriddhi lakshana}

Adhyasthi means extra growth of bone which may leads other complications such as; Acromegaly in which abnormal growth of hands, feet and jaw occurred. Paget's disease is another condition related to excessive growth of bone in which bone enlargement occurs particularly to pelvis, spine 
and skull area. Melorheostosis is other similar types of condition which involves thickening of cortical bone ${ }^{4-7}$.

\section{$>$ Asthi kshaya lakshana}

Asthi kshaya means decrease in quality of Asthi dhatu which resembles condition of osteoporosis as per modern science.
The symptoms of such condition may involve joint pain, vertigo, lightness in bones, fatigue and lethargy, etc. Figure 1 depicted some manifestations related to the abnormalities in Asthi dhatu

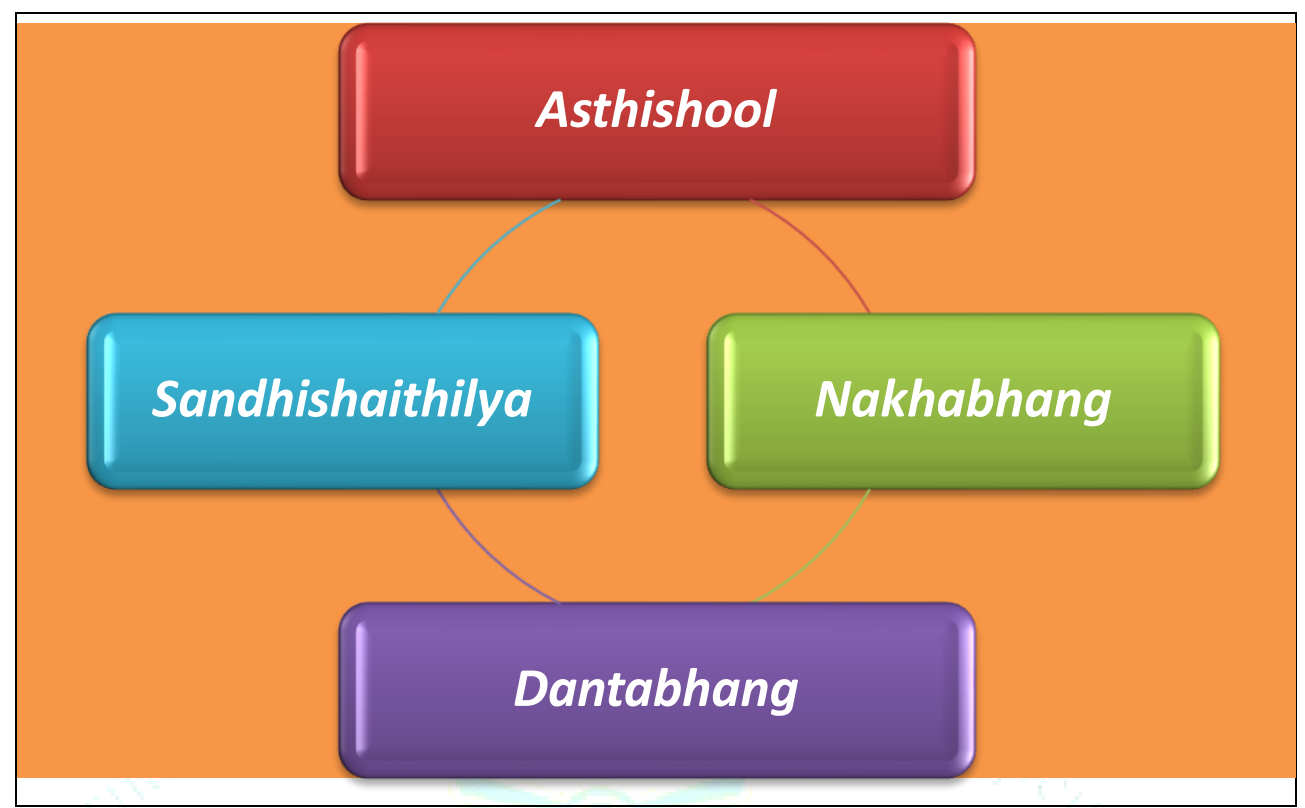

Figure 1: Some manifestations related to the abnormalities in Asthi dhatu

\section{Causes for Abnormalities in Asthi dhatu:}

$>$ Aging

$>$ Physical stress

$>$ Malnutrition

$>$ Degeneration of bone tissue in diseases condition

$>$ Surgical trauma and injury

$>$ Environmental effects

$>$ Ahara-Viahar that vitiate Vata

\section{Role of Basti karma}

Ayurveda mentioned various approaches to restore health status of Asthi dhatu including Basti karma which offers following beneficial effects:

* Majja gata vikaras can be treated effectively with the help of Kala basti and Karma Basti.

* Basti karma regulates function of Vata thus maintain physiology of bone.

* Basti pacify vitiated Doshas and enhances nutritional supply.

* Basti imparts direct effect on Asthi and Majja Dhatu and facilitate functions of channels that supply to bone tissues.

* Sukshma Guna of Basti drugs reaches up to micro circulation and enhances nutritional supply to all parts.

* Thikshna Guna of ingredients used for Basti karma break aggravated Mala and Dosha thereby facilitate their evacuation from body.
* Snigdha Guna of Basti Dravyas liquefies vitiated Doshas and removes blockage of channels.

* Sneha of Basti increases permeability thus balances process of exchange and diffusion thus improves nourishment of bone and other tissue.

* Utkleshana or Samana effects of Basti pacify Dushya of Srothas thus acts on initial stage and perform function of Samprapti Vighatana of Asthi pradoshaj vikara.

* Basti helps to maintain integrity of peripheral nerve and prevents process of degeneration thus reduces loss of integrity of bone tissue.

* Basti promote normal bacterial flora of body require for process of digestion and assimilation thus boost regeneration of tissues.

* Basti enhances process of absorption, imparts neural activation and causes mechanical stimulation therefore helps in degenerative disorders.

* Basti relieve Vata thus helps in symptoms such as; pain, stiffness and tenderness ${ }^{5-10 .}$

\section{Conclusion}

Asthi is vital Dhatus of body provides shape and physical integrity to the body. Asthi protects organs of body from external shock, maintain posture of body, provide strength and stability, support Majja Dhatu, imparts compactness of body, Asthi dhatu connects tissues and regulates functions of movement. The abnormal state of Asthi dhatus may be considered as Vriddhi or Kshaya. Ayurveda described various approaches to restore Asthi dhatus and Basti chikitsa is one such approach. Basti karma regulates normal state of Vata, pacify vitiated Doshas, enhances nutritional supply, facilitate 
functions of channels supplying to bony tissues, helps in Samprapti Vighatana of Asthi pradoshaj vikara, Basti prevents process of degeneration and boost regeneration of tissues thus strengthen physiological functioning of Asthi dhatu.

\section{References}

1. Kaviraj Ambikadutta Shastri, Sushrut Samhita of Maharshi Sushrut, volume 1, Sutrasthana 5/3, Publisher: Chaukhamba Sanskrit Pratishthana, Varanasi (2012).

2. Acharya Vidyadharshukla, Prof. Ravidutta Tripathi, Charak Samhita of Agnivesha, Volume 2, Chikitsa Sthana 15/32, Publisher: Chaukhamba Sanskrit Pratishthana, Delhi (2010).

3. Acharya Vidyadharshukla, Prof. Ravidutta Tripathi, Charak Samhita of Agnivesha, Volume 2, Chikitsa Sthana 15/21, Publisher: Chaukhamba Sanskrit Pratishthana, Delhi (2010).

4. Acharya Vidyadharshukla, Prof. Ravidutta Tripathi, Charak Samhita of Agnivesha, Volume 2, Chikitsa Sthana 15/30, Publisher: Chaukhamba Sanskrit Pratishthana, Delhi (2010).

5. Susruta: Susruta Samhita: with commentaries Nibandhasamgraha by Dalhana and Nyayacandrika by Gayadasa: edited by Vaidya Yadavji Trikamji Acharya
Chaukhamba Surbharti Prakashan, Varanasi: reprint (2012), Sutra Sthana chapter $15 / 3$

6. Vagbhata, Ashtanga Hrudaya, with Ayurveda Rasayana Sanskrit commentary by Hemadri, Vidyotini, hindi commentary by Kaviraja Atrideva Gupta, edited by Vaidya Yadunandana Upadhyaya, reprinted in 2010,Choukhambha Prakashan, Varanasi, Sutra Sthana chapter 11/19

7. Acharya Vidyadharshukla, Prof. Ravidutta Tripathi, Charak Samhita of Agnivesha, Volume 1, Vimana Sthana, 5/16, Publisher: Chaukhamba Sanskrit Pratishthana, Delhi (2010).

8. Agnivesha Charakasamhita with Ayur-veda Deepika commentary of Chakrapani-datta revised by Charaka andDridhabala, edited by Vaidya Y. T. Acharya, Chaukamba publishers, reprint 2013 Sidhisthana, Chapter 3, sloka 18 p. 692

9. Sharangdha: Sharangadhar Samhita, with Hindi Commentary Jiwanprada By Dr Smt. Shailaja Srivastava, Editon -4;2005, Chaukhamba Orientalia, Varanas, Poorva Khanda, Chapter5/16-17

10. Kaviraj Ambikadutta Shastri, Sushrut Samhita of Maharshi Sushrut, volume 1, Sutrasthana, 15/5, Publisher: Chaukhamba Sanskrit Pratishthana, Varanasi (2012). 